\title{
KEDUDUKAN MAHKAMAH KONSTITUSI SEBAGAI LEMBAGA NEGARA BERDASARKAN UNDANG-UNDANG DASAR 1945
}

\author{
Johansyah \\ Fakultas Hukum Universitas Palembang \\ johansyah@unpal.ac.id
}

\begin{abstract}
The Constitutional Court is the executive branch of the judiciary that is independent and separate from other branches of power, namely the government (executive) and legislative institutions. The Constitutional Court as a first and last level judiciary does not have an organizational structure as large as the Supreme Court which is the peak of a judicial system whose structure is vertically and horizontally covers five judicial environments, namely the general court environment, the state administrative court environment, the religious court environment, and military court environment. As an organ of judicial power that operates the judicial function, the Constitutional Court is independent, both structurally and functionally. The functions and authorities of the Constitutional Court based on Law No. 24 of 2003, namely the Constitutional Court has the authority to hear: Test the laws against the Republic of Indonesia 1945 Constitution; Decide on authority disputes between state institutions whose authority is granted by the Republic of Indonesia 1945 Constitution; Decide the dissolution of political parties; Decide disputes about election results; Give a verdict on the opinion of the House of Representatives that the President and / or Vice-President are suspected of violating the law in the form of treason, corruption, bribery, other serious crimes, or despicable acts, or no longer fulfill the conditions as President and or Vice President, as intended in the Republic of Indonesia 1945 Constitution.
\end{abstract}

Keywords: Constitutional Court; State institutions; Judicial Power

ABSTRAK

Mahkamah Konstitusi merupakan pelaksana cabang kekuasaan kehakiman (judiciary) yang merdeka dan terpisah dari cabang-cabang kekuasaan lain, yaitu pemerintah (executive) dan lembaga permusyawaratan-perwakilan (legislature). Mahkamah Konstitusi sebagai lembaga peradilan tingkat pertama dan terakhir tidak mempunyai struktur organisasi sebesar Mahkamah Agung yang merupakan puncak sistem peradilan yang strukturnya bertingkat secara vertikal dan secara horizontal mencakup lima lingkungan peradilan, yaitu lingkungan peradilan umum, lingkungan peradilan tata usaha negara, lingkungan peradilan agama, dan lingkungan peradilan militer. Sebagai organ kekuasaan kehakiman yang menjalankan fungsi kehakiman, Mahkamah Konstitusi bersifat independen, baik secara struktural maupun fungsional. Adapun fungsi dan wewenang Mahkamah Konstitusi berdasarkan Undang-undang No. 24 Tahun 2003, yaitu Mahkamah Konstitusi berwenang mengadili: Menguji undang-undang terhadap UUD RI 1945; Memutus sengketa kewenangan antar lembaga negara yang kewenangannya diberikan oleh UUD RI 1945; Memutus pembubaran partai politik; Memutus perselisihan tentang hasil pemilu; Memberi putusan atas pendapat Dewan Perwakilan Rakyat bahwa Presiden dan atau Wakil Presiden diduga telah melakukan pelanggaran hukum berupa penghianatan terhadap negara, korupsi, penyuapan, tindak pidana berat lainnya, atau perbuatan tercela, danatau tidak lagi memenuhi syarat sebagai Presiden dan atau Wakil Presiden, sebagaimana dimaksud dalam UUD RI 1945.

Kata Kunci: Mahkamah Konstitusi; Lembaga Negara; Kekuasaan Kehakiman

\section{PENDAHULUAN}

Salah satu lembaga negara yang dibentuk setelah amandemen UUD 1945 untuk memperkuat pranata demokrasi dalam struktur ketatanegaraan adalah Mahkamah Konstitusi. Kedudukan Mahkamah Konstitusi diletakkan dalam konsep kekuasaan kehakiman merdeka dan menjadi salah satu pelaksana kekuasaan kehakiman. Bab IX tentang Kekuasaan Kehakiman UUD 1945
Pasal 24 (i) menyatakan kekuasaan kehakiman merupakan kekuasaan yang merdeka untuk menyelenggarakan peradilan guna menegakkan hukum dan keadilan. Selanjutnya dalam Pasa1 24 ayat (2) ditentukan bahwa kekuasaan kehakiman dilakukan oleh sebuah mahkamah agung dan badan peradilan di bawahnya dalam lingkungan peradilan umum, lingkungan peradilan agama, lingkungan peradilan 
militer, serta lingkungan peradilan tata usaha negara dan oleh Mahkamah Konstitusi. ${ }^{1}$

Sebagaimana diketahui bahwa

konstitusi Indonesia telah mengalami perubahan dalam satu rangkaian empat tahap, yaitu pada tahun 1999, 2000, 2001, dan 2002 (UUD RI 1945). Salah satu perubahan dari UUD RI 1945 adalah dengan telah diadopsi prinsip-prinsip baru dalam sistem ketatanegaraan antara lain prinsip pemisahan kekuasaan dan checks and balances sebagai pengganti sistem supremasi parlemen. Dalam Pasal 24C hasil perubahan ketiga UUD RI 1945, dimasukkannya ide pembentukan Mahkamah Konstitusi kedalam konstitusi negara kita sebagai organ konstitusional baru yang sederajat kedudukannya dengan organ konstitusi lainnya. Fungsi Mahkamah Konstitusi telah dilembagakan berdasarkan Undang-undang Nomor 24 tahun 2003 tentang Mahkamah Konstitusi.

Dalam konsep pemisahan kekuasaan, seluruh cabang-cabang kekuasaan yang dibentuk memiliki fungsi dan wewenang masing-masing yang terpisah secara tegas. Dan dengan konsep kekuasaan ini, dapat diletakkan keberadaan kelembagaan negara dalam posisi dan kedudukan yang setara atau sederajat. Oleh karena itu, restrukturisasi lembaga MPR telah menjadikan susunan dan sistem kelembagaan negara menjadi sama kedudukannya. Tidak ada lagi istilah lembaga tertinggi dan lembaga tinggi negara, yang ada adalah istilah lembaga negara. Dan Mahkamah Konstitusi merupakan salah satu lembaga negara yang keberadaan dan kewenangannya diatur UUD. Hal yang mendasar mengenai kedudukan lembaga pelaksana kekuasaan kehakiman ini adalah adanya soal kemandirian (independensi). Kemandirian kekuasaan kehakiman merupakan salah satu prinsip penting dalam negara demokrasi. Kemandirian kekuasaan kehakiman juga merupakan salah satu syarat dan ciri penting dalam negara hukum, selain adanya asas legalitas yang artinya pemerintah

\footnotetext{
Mahkamah Konstitusi RI, Pengantar: Jimly Asshidiqie, Cetak Biru, Membangun Mahkamah Konstitusi Sebagai Institusi Yang Modern dan Bertanggungjawab, Jakarta, 24 Desember 2004, Hlm.16.
}

harus bertindak berdasarkan semata-mata hukum yang berlaku, adanya jaminan perlindungan hak asasi manusia, dan pemerintahan berdasarkan sistem konstitusi dan hukum dasar.

Dengan adanya kemandirian kekuasaan kehakiman dari cabang kekuasaan lainnya, badan atau lembaga pelaksananya diharapkan dapat melakukan kontrol hukum terhadap kekuasaan negara lainnya. Di samping itu, untuk mencegah dan mengurangi kecenderungan penyalahgunaan wewenang atau kekuasaan. Tidak adanya kemandirian kekuasaan kehakiman terutama dari kekuasaan pemerintah akan membuka peluang terjadinya penyalahgunaan kekuasaan dan pengabaian hak asasi manusia oleh penguasa. Sebab kekuasaan kehakiman secara konstitusional memiliki wewenang untuk menjalankan fungsi kontrol terhadap kekuasaan pemerintah.

Mengingat pentingnya kemandirian kekuasaan kehakiman ini, dan merupakan suatu hal yang sangat prinsipiil, maka harus ditegaskan dan dijamin dalam konstitusi dan peraturan perundang-undangan lainnya. Pasa1 24 Ayat (1) UUD 1945 hasil perubahan menyatakan secara tegas dan jelas bahwa Kekuasaan kehakiman merupakan kekuasaan yang merdeka untuk menyelenggarakan peradilan guna menegakkan hukum dan keadilan. UUD menggunakan istilah merdeka yang sesungguhnya tidak berbeda pengertiannya dengan istilah kemandirian.

Mahkamah Konstitusi yang diletakkan secara konsepsi dan pengaturannya dalam UUD merupakan bagian dan salah satu pelaksana kekuasaan kehakiman bersama Mahkamah Agung yang secara resmi dibentuk berdasarkan Undang-undang Nomor 24 tahun 2003.

\section{PEMBAHASAN}

\section{A. Sejarah Pembentukan Mahkamah Konstitusi}

Pembentukan mahkamah konstitusi sebagai lembaga yang tersendiri karena kebutuhan adanya suatu pengadilan yang secara khusus melakukan pengujian terhadap produk undang-undang (dalam istilah Hans Kelsen, statute and customary law) yang bertentangan dengan konstitusi (undang- 
undang dasar). Ide ini, bermula dari Prof. Hans Kelsen, guru besar kenamaan dari Universitas Wina yang mengusulkan dibentuknya suatu lembaga yang diberi nama 'Verfassungsgerichtshoft' atau Mahkamah Konstitusi (Constitutional Court). Gagasan Kelsen ini, kemudian diterima dengan bulat dan diadopsikan ke dalam naskah Undang-undang Dasar Tahun 1920 yang disahkan dalam Konvensi Konstitusi pada tanggal 1 Oktober 1920 sebagai Konstitusi Federal Austria. ${ }^{2}$

Menurut Hans Kelsen kemungkinan muncul persoalan konflik antara norma yang lebih tinggi dengan yang lebih rendah, bukan saja berkaitan antara undang-undang (statute) dan putusan pengadilan, tetapi juga berkaitan dengan hubungan antara konstitusi dan undang-undang. Ini adalah problem inkonstitusionalitas dari undang-undang. Suatu undang-undang (statute) hanya berlaku dan dapat diberlakukan jika sesuai dengan konstitusi, dan tidak berlaku jika bertentangan dengan konstitusi. Suatu undang-undang hanya sah jika dibuat berdasarkan ketentuanketentuan konstitusi. Karena itu diperlukan suatu badan atau pengadilan yang secara khusus untuk menyatakan inkonstitusionalitas dari suatu undang-undang yang sedang berlaku. Menurut Kelsen, suatu undangundang yang telah dinyatakan tidak berlaku oleh mahkamah konstitusi tidak dapat diterapkan oleh lembaga-lembaga yang lain. Jika pengadilan biasa berwenang untuk menilai konstitusionalitas dari suatu undangundang hanya berhak menolak untuk menerapkannya atau mengesampingkannya dalam kasus-kasus konkrit yang diputuskan, tetapi organ yang lainnya tetap berkewajiban menerapkan undang-undang itu. Sepanjang suatu undang-undang tidak dinyatakan tidak berlaku, adalah tetap "constitutional" dan tidak "unconstitutional", walaupun rasanya undang-undang itu bertentangan dengan konstitusi. Dengan demikian, suatu undangundang dapat dinyatakan tidak berlaku oleh pembentuk undang-undang yaitu legislatif dan juga dapat dinyatakan tidak berlaku oleh

2 Jimly Asshidiqqie. Model-Model Pengujujian Konstitusional Berbabagai Negara. Konstitusi Press. Jakarta. 2005. Hlm. 33 mahkamah konstitusi. Pemikiran Hans Kelsen ini tidak lepas pelaksanaan teori hukum murni dan teori hiraki norma yang sangat terkenal yang dikemukakannya dimana konstitusi ditempatkan sebagai norma hukum yang superior dari undang-undang biasa.

Jadi pada awalnya mahkamah konstitusi merupakan suatu lembaga yang dimaksudkan hanya untuk menguji konstitusionalitas (constitutional review) dari suatu undang-undang terhadap konstitusi. Karena itu mahkamah konstitusi sering disebut sebagai "the guardian of the constitution” (pengawal konstitusi).

Dengan kewenangannya yang dapat menyatakan inkonstitusionalitas dari suatu undang-undang, posisi mahkamah konstitusi berada ada di atas lembaga pembentuk undang-undang. Itulah sebabnya sejak awal Hans Kelsen telah menyatakan bahwa lembaga ini dibentuk dengan kekuasaan yang berada di atas legislatif dan mestinya secara politik tidak dikehendaki, khususnya jika memutuskan bahwa suatu undang-undang adalah inkonstitusional. Karena itu bagi negara-negara yang menempatkan superioritas parlemen yang cukup besar karena dianggap cerminan kedaultan rakyat, tidak menempatkan mahkamah konstitusi dalam posisi di atas pembentuk undangundang, seperti Dewan Konstitusi Perancis yang hanya berwenang menguji konstitusionalitas dari suatu rancangan undang-undang yang telah dibahas oleh parlemen tetapi belum diberlakukan. Bahkan Kerajaan Inggeris dan Kerajaan Belanda tidak membentuk Mahkamah Konstitusi, dengan prinsip bahwa parlemenlah satu-satunya lembaga yang membentuk serta mengetahui sah tidaknya suatu undang-undang. ${ }^{3}$

Dalam perkembangannya, konsep dasar pembentukan mahkamah konstitusi di berbagai negara sangat terkait dengan perkembangan prinsip-prinsip dan teori ketatanegaraan modern yang dianut oleh berbagai negara yang menganut prinsip konstitusionalisme, prinsip negara hukum, prinsip check and balances, prinsip demokrasi

\footnotetext{
${ }^{3}$ Panitia Ad Hoc 1 Badan Pekerja MPR RI Untuk Peresiapan Perubahan UUD 1945. Tahun 2000.
} 
dan jaminan perlindungan hak asasi manusia prinsip peradilan yang bebas dan tidak memihak serta pengalaman politik dari masing-masing negara. Keberadaan mahkamah konstitusi dibutuhkan dalam menegakkan prinsip-prinsip tersebut.

Konstitusionalisme merupakan paham yang berprinsip bahwa pelaksanaan kekuasaan negara oleh organ-organ negara harus berdasarkan ketentuan-ketentuan konstitusi. Pelanggaran terhadap konstitusi tidak dapat ditolerir karena akan menimbulkan kekuasaan yang tiran dan semena-mena. Karena itu prinsip konstitusonalisme juga terkait dengan prinsip pemisahan dan pembatasan kekuasaan (check and balances),yaitu kekuasaan lembagalembaga negara dibagi secara seimbang. Kekuasaan negara tidak boleh bertumpu pada satu lembaga negara karena akan dapat menimbulkan penyelahgunaan kekuasaan negara. Dalam mengawasi pelaksanaan kekuasaan lembaga-lembaga negara tersebut, agar tetap sesuai dengan kehendak rakyat diperlukan prinsip demokrasi dan penghormatan atas hak asasi mansuia. Artinya, karena kekuasaan negara bersumber dari rakyat maka akan selalu dapat dikontrol oleh rakyat dan selalu mengormati hak-hak dasar rakyat. Alat ukur bagi rakyat untuk mengawasi penyelenggaraan kekuasaan negara oleh lembaga negara adalah hukum dan konstitusi. Disnilah prinsip negara hukum dan rule of law menjadi penting. Untuk menilai secara obyektif dan independen apakah suatu tindakan negara (lembagalembaga negara) melanggar konstitusi atau hukum, dibutuhkan suatu lembaga yang mengadili dan memutuskannya yang dijamin oleh konstitusi. Di sinilah konsep dasar dibutuhkannya mahkamah konstitusi yang berkembang sekarang ini.

Sejarah berdirinya lembaga Mahkamah Konstitusi (MK) di Indonesia diawali dengan diadopsinya ide Mahkamah Konstitusi (Constitutional Court) dalam amandemen konstitusi yang dilakukan oleh Majelis Permusyawaratan Rakyat (MPR) pada tahun 2001 sebagaimana dirumuskan dalam ketentuan Pasal 24 ayat (2), Pasal 24C, dan Pasal 7B Undang-Undang Dasar 1945 hasil Perubahan Ketiga yang disahkan pada 9 Nopember 2001. Ide pembentukan Mahkamah Konstitusi merupakan salah satu perkembangan pemikiran hukum dan kenegaraan modern yang muncul di abad ke20.

Setelah disahkannya Perubahan Ketiga UUD 1945 maka dalam rangka menunggu pembentukan Mahkamah Konstitusi, MPR menetapkan Mahkamah Agung (MA) menjalankan fungsi Mahkamah Konstitusi untuk sementara sebagaimana diatur dalam Pasal III Aturan Peralihan UUD 1945 hasil Perubahan Keempat.

DPR dan Pemerintah kemudian membuat Rancangan Undang-Undang mengenai Mahkamah Konstitusi. Setelah melalui pembahasan mendalam, DPR dan Pemerintah menyetujui secara bersama UU Nomor 24 Tahun 2003 tentang Mahkamah Konstitusi pada 13 Agustus 2003 dan disahkan oleh Presiden pada hari itu (Lembaran Negara Nomor 98 dan Tambahan Lembaran Negara Nomor 4316).

Mahkamah Konstitusi Republik Indonesia adalah lembaga (tinggi) negara yang kedudukannya sederajat dengan Mahkamah Agang (MA).

\section{B. Mahkamah Konstitusi RI dalam Sistem Ketatanegaraan Indonesia}

Pemikiran mengenai pentingnya suatu mahkamah konstitusi telah muncul dalam sejarah ketatanegaraan Indonesia sebelum merdeka. Pada saat pembahasan rancangan UUD di Badan Penyelidik Usaha-usaha Persiapan Kemerdekaan Indonesia (BPUPKI), anggota BPUPKI Prof. Muhammad Yamin telah mengemukakan pendapat bahwa Mahkamah Agung (MA) perlu diberi kewenangan untuk membanding undangundang. Namun ide ini ditolok oleh Prof. Soepomo berdasarkan dua alasan, pertama, UUD yang sedang disusun pada saat itu (yang kemudian menjadi UUD 1945) tidak menganut paham trias politika. Kedua, pada saat itu jumlah sarjana hukum kita belum 
banyak dan belum memiliki pengalaman mengenai hal ini. ${ }^{4}$

Ide pembentukan Mahkamah konstitusi pada era reformasi, mulai dikemukakan pada masa sidang kedua Panitia Ad Hoc I Badan Pekerja MPR RI (PAH I BP MPR), yaitu setelah seluruh anggota Badan Pekerja MPR RI melakukan studi banding di 21 negara mengenai konstitusi pada bulan Maret-April tahun 2000. Ide ini belum muncul pada saat perubahan pertama UUD 1945, bahkan belum ada satu pun fraksi di Majelis Permusyawaratan Rakyat (MPR) yang mengajukan usul itu. Nampaknya para anggota MPR sangat terpengaruh atas temuannya dalam studi banding tersebut. Walaupun demikian pada Sidang Tahunan MPR bulan Agustus tahun 2000, rancangan rumusan mengenai mahkamah konstitusi masih berupa beberapa alternatif dan belum final $^{5}$.

Sesuai rancangan tersebut, mahkamah konstitusi di tempatkan dalam lingkungan mahkamah agung, dengan kewenangan untuk melakukan uji materil atas undang-undang; memberikan putusan atas pertentangan antar undang-undang; serta kewenangan lainnya yang diberikan undang-undang. Ada usulan alternatif, agar di luar kewenangan tersebut mahkamah konstitusi juga diberi kewenangan untuk memberikan putusan atas persengketaan kewenangan antarlembaga negara, antar pemerintah pusat dengan pemerintah daerah dan antar pemerintah daerah.

Setelah dibahas kembali pada masa sidang PAH I BP MPR RI tahun 2000/2001, yaitu dalam rangka persiapan draft perubahan ketiga Undang-Undang Dasar Negara repbulik Indonesia Tahun 1945 (UUD 1945) untuk disahkan pada sidang tahunan 2001, terjadi banyak perubahan mengenai rumusan tentang mahkamah konstitusi. Persoalan pokok yang pertama adalah apakah mahkamah konstitusi ditempatkan di

\footnotetext{
${ }^{4}$ Jimli Asshidiqy. Mahkamah Konstitusi Dalam Sistem Ketatanegaraan RI. Bahan Ceramah yang disampaikan pada tanggal 27 September 2005 di Univ. Mataram

Ketetapan MPR RI No. IX/MPR/2000. Tentang Penugasan Badan Pekerja MPR untuk mempersiapakn Perubahan UUD 1945.
}

lingkungan mahkamah agung atau ditempatkan terpisah dari lingkungan mahkamah agung tetapi masih dalam rumpun kekuasaan kehakiman, dan persoalan kedua apa saja yang menjadi kewenangan mahkamah konstitusi.

Pertama, disepakati bahwa mahkamah konstitusi ditempatkan terpisah dan di luar lingkungan mahkamah agung akan tetapi tetap dalam lingkungan kekuasaan kehakiman, dengan pertimbangan bahwa lembaga ini adalah lembaga yang sangat penting untuk membangun negara yang berdasar sistem konstitusionalisme, sehingga lembaga ini berdiri sejajar dengan lembagalembaga negara lainnya yang secara tegas ditentukan kedudukan dan kewenangannya dalam undang-undang dasar. Terdapat kekhawatiran bahwa mahkamah agung tidak akan mampu membawa misi besar mahkamah konstitusi untuk membangun sistem konstitusionalisme karena pekerjaan mahkamah agung yang pada saat itu tidak mampu menyelesaikan perkara-perkara kasasi dan peninjauan kembali yang menumpuk. Jika ditambah lagi dengan tugas-tugas mahkamah konstitusi dikhawatirkan pekerjaan mahkamah agung akan terbengkalai. Pada sisi lain dibutuhkan satu mahkamah tersendiri yang berdiri sejajar dengan mahkamah agung dan lembagalembaga negara lainnya untuk menjalankan tugas mengawal sistem konstitusionalisme Indonesia. Dengan demikian posisi mahkamah konstitusi dalam ketatanegaraan Indonesia menjadi kuat.

Kedua, kewenangan mahkamah konstitusi disepakati untuk ditentukan secara limitatif dalam undang-undang dasar. Kesepakatan ini mengandung makna penting, karena mahkamah konstitusi akan menilai konstitusionalitas dari suatu undang-undang atau sengketa antar lembaga negara yang kewenangannya ditentukan dalam undangundang dasar, karena itu sumber kewenangan mahkamah konstitusi harus langsung dari undang-undang dasar. Dengan demikian tidak ada ada satu lembaga negara yang dapat mempermasalahkan atau menggugurkan putusan mahkamah konstitusi. Pada sisi lain mahkamah konstitusi sebagai lembaga negara 
pengawal konstitusi tidak melakukan tindakan atau memberikan putusan yang keluar dari kewenangannya yang secara limitatif ditentukan dalam undang-undang dasar. Demikian juga halnya pembentuk undangundang tidak dapat mengurangi kewenangan mahkamah konstitusi melalui ketentuan undang-undang sehingga melumpuhkan ide dasar pembentukan mahkamah konstitusi. Dengan prinsip inilah dihapus kesepakatan awal yang memungkinkan adanya kewenangan lain mahkamah konstitusi yang ditentukan undang-undang sebagaiman draft awal PAH I BP MPR RI tahun 2000.

Menurut UUD 1945, Mahkamah Konstitusi RI, memiliki 4 kewenangan, yaitu :

1. menguji undang-undang terhadap undang-undang dasar,

2. memutus sengketa kewenangan lembaga negara yang kewenangannya diberikan undang-undang dasar;

3. memutus pembubaran partai politik;

4. memutus perselisihan tentang hasil pemlihan umum.

Disamping itu dalam rangka proses pemberhentian presiden dan/atau wakil presiden, atas permintaan Dewan Perwakilan Rakyat (DPR), Mahkamah Konstitusi RI berkewajiban untuk memutus pendapat DPR bahwa Presiden dan/atu Wakil Presiden telah melakukan pelanggaran hukum berupa pengkhianatan terhadap negara, korupsi, penyuapan, tindak pidana berat lainnya, atau perbuatan tercela dan/atau pendapat bahwa Presiden dan/atau wakil Presiden tidak lagi memenuhi syarat sebagai Presiden dan/atau Wakil Presiden.

Pembentukan mahkamah konstitusi diperlukan untuk menegakkan prinsip negara hukum Indonesia dan prinsip konstitusionalisme. Artinya tidak boleh ada undang-undang dan peraturan perundangundangan lainnya yang bertentangan dengan undang-undang dasar sebagai puncak dari tata urutan perundang-undangan di Indonesia. Dalam rangka pengujian undang-undang terhadap undang-undang dasar dibutuhkan sebuah mahkamah dalam rangka menjaga prinsip konstitusionalitas hukum. Tugas mahkamah konstitusilah yang menjaga konstitusionalitas hukum itu.
Pembentukan mahkmah konstitusi juga terkait dengan penataan kembali dan reposisioning lembaga-lembaga negara yang sebelum perubahan UUD 1945 berlandaskan pada supremasi MPR sebagai lembaga tertinggi negara. Perubahan Pasal 1 ayat (2) UUD 1945 yang sebelum perubahan berbunyi "Kedaulatan adalah ditangan rakyat dan dilakukan sepenuhnya oleh Majelis Permusyawaratan Rakyat", diubah menjadi "Kedaulatan berada ditangan rakyat dan dilaksanakan menurut undang-undang dasar", telah membawa implikasi yang sangat luas dan mendasar dalam sistem ketatanegaraan Indonesia. Artinya, sebelum perubahan, kedaulatan rakyat berpuncak pada MPR, dan MPR-lah sebagai penyelesaian final atas setiap masalah ketatanegaraan yang muncul baik atas konstitusionalitas dari suatu undangundang maupun penyelesaian akhir sengketa antar lembaga negara. Dengan dasar konsepsional inilah ketetapan MPR RI No. III Tahun 2000 menentukan bahwa pengujian undang-undang terhadap undang-undang dasar dilakukan oleh MPR dan setiap lembaga negara melaporkan penyelenggaraan kinerjanya kepada MPR setiap tahun.

Implikasi perubahan Pasal 1 ayat (2) tersebut, posisi MPR sejajar dengan lembagalembaga negara lainnya dan masing-masing lembaga negara adalah pelaksana kedaulatan rakyat sesuai tugas dan kewenangannya yang ditentukan undang-undang dasar. Dengan demikian MPR melaksanakan kedaulatan rakyat untuk mengubah dan menetapkan undang-undang dasar, melantik presiden dan wakil presiden, memberhentikan presiden dan/atau wakil presiden sesuai ketentuan undang-undang dasar, serta dalam hal-hal tertentu mengangkat presiden dan/atau wakil presiden. Mahkamah konstitusi merupakan pelaksana kedaulatan rakyat untuk menguji konstitusionalitas undang-undang terhadap undang-undang dasar, memutus sengketa kewenangan antara lembaga negara yang kewenangannya diatur dalam undang-undang dasar, memutus sengketa pemilihan umum serta memutus pembubaran partai politik. Demikian juga lembaga negara yang lainnya adalah pelaksana kedaulatan rakyat sesuai 
tugas dan wewenangnya yang ditentukan dalam undang-undang dasar.

Kewenangan mahkamah konstitusi yang dapat menyatakan tidak mempunyai kekuatan atas suatu undang-undang produk legislatif produk DPR dan Presiden serta memutuskan sengketa antar lembaga negara, menunjukkan posisinya yang lebih tinggi dari lembaga-lembaga negara lainnya. Hal ini wajar saja karena Undang-Undang Dasar memberikan otoritas kepada Mahkamah Konstitusi sebagai penafsir paling absah dan authentik terhadap konstitusi. Walaupun demikian, pendapat dan penafsiran hukum mahkamah konstitusi yang dapat diterima penafsiran yang dikeluarkan melalui putusannya atas permohonan yang diajukan kepadanya sesuai lingkup kewenangannya untuk mengadili dan memutus suatu perkara.

Dengan posisi yang demikian penting itu undang-undang dasar menetapkan kwalifikasi yang sangat ketat bagi anggota mahkamah konstitusi, antara lain memiliki integiritas dan kepribadian yang tidak tercela, adil, negarawan yang menguasai konstitusi dan ketatanegaraan. Sembilan orang anggota mahkamah konstitusi juga merepresentasikan tiga unsur lembaga negara yaitu masingmasing-masing 3 orang anggota yang diajukan oleh presiden, DPR dan mahkamah agung.

\section{Fungsi dan Wewenang Mahkamah Konstitusi (MK)}

Dalam menjalankan peranannya sebagai penjaga konstitusi, yaitu melakukan kekuasaan kehakiman seperti diatur dalam ketentuan Pasal 24 ayat (2) UUD RI 1945. Sedangkan yang dimaksud dengan kekuasaan kehakiman adalah kekuasaan yang merdeka untuk menyelenggarakan peradilan guna menegakkan hukum dan keadilan mahkamah konstitusi diberi beberapa kewenangan (Pasal 24 ayat (1) UUD RI 1945). Adanya sebuah kekuasaan kehakiman yang bebas adalah salah satu prasyarat bagi negara hukum disamping syarat-syarat yang lainnya.

Untuk memahami peran yang dilakukan oleh Mahkamah Konstitusi, haruslah dikaji dengan komprehensif kewenangan-kewenangan yang diberikan oleh
UUD RI 1945 kepada lembaga ini. Pasal 24 C ayat (1) menyebutkan bahwa Mahkamah Konstitusi berwenang untuk mengadili pada tingkat pertama dan terakhir dimana putusannya bersifat final. Dari ketentuan tersebut berarti Mahkamah Konstitusi bersifat tunggal yang tidak mempunyai peradilan yang berada dibawahnya dan tidak merupakan bawahan dari lembaga lain. Hal ini berbeda dengan Mahkamah Agung yang mempunyai peradilan-peradilan dibawahnya dan merupakan puncak dari peradilan-peradilan yang berada dibawahnya. Dengan ketunggalannya dapat dikatakan bahwa Mahkamah Konstitusi adalam sebuah forum khusus untuk melakukan kewenangannya. Didalam menjalankan perannya sebagai penjaga konstitusi, maka Mahkamah Konstitusi Republik Indonesia diberi kewenangan seperti yang diatur dalam Pasal 24C ayat (1) UUD RI 1945 yang kemudian dipertegas dalam Undang-undang No. 24 Tahun 2003 tentang Mahkamah Konstitusi yang menentukan bahwa Mahkamah Konstitusi berwenang mengadili:

b. Menguji undang-undang terhadap UUD RI 1945;

c. Memutus sengketa kewenangan antar lembaga negara yang kewenangannya diberikan oleh UUD RI 1945;

d. Memutus pembubaran partai politik;

e. Memutus perselisihan tentang hasil pemilu;

f. Memberi putusan atas pendapat Dewan Perwakilan Rakyat bahwa Presiden dan atau Wakil Presiden diduga telah melakukan pelanggaran hukum berupa penghianatan terhadap negara, korupsi, penyuapan, tindak pidana berat lainnya, atau perbuatan tercela, danatau tidak lagi memenuhi syarat sebagai Presiden dan atau Wakil Presiden, sebagaimana dimaksud dalam UUD RI 1945.

Pelanggaran hukum yang diduga dilakukan presiden yang disebut dalam pasal 10 ayat (2) UU No. 24, 2003, telah diperjelas dalam ayat

(3) dengan memberi batasan sebagai berikut:

a. Penghianatan terhadap negara adala tindak pidana terhadap keamanan 
negara sebagaimana diatur dalam undang-undang;

b. Korupsi dan penyuapan adalah tindak pidana korupsi atau penyuapan sebagaimana diatur dalam undangundang;

c. Tindak pidana berat lainnya adalah tindak pidana yang diancam dengan pidana penjara 5 (lima) tahun atau lebih;

d. Perbuatan tercela adalah perbuatanperbuatan yang dapat merendahakan martabat Presiden danatau Wakil Presiden;

e. Tidak lagi memenuhi syarat sebagai presiden danatau wakil presiden adalah syarat sebagaimana dtentukan dalam pasala 6 UUD RI 1945.

Kewenangan yang diberikan kepada Mahkamah Konstitusi dapat dibedakan menjadi dua. Yaitu kewenangan utama, dan kewenangan tambahan. Kewenangan utama meliputi: (a) pengujian undang-undang terhadap UUD, (b) memutus keluhan konstitusi yang diajukan oleh rakyat terhadap penguasa, Mahkamah Konstitusi diberi kewenangan utamanya yaitu untuk memutus constituional complain yang diajukan rakyat terhadap penguasa, Mahkamah Konstitusi wajib menerima dan memutus permohonan dari rakyat bilamana adanya produk peraturan yang berada dibawah undang-undang seperti Keputusan Presiden, Penetapan Presiden, Instruksi Presiden danatau Peraturan Presiden untuk diajukan judicial review. (c) memutus sengketa kewenangan antar lembaga negara. Sedangkan kewenangan tambahan dapat bervariasi antara negara satu dengan yang lainnya. UUD RI 1945 memberikan kewenangan tambahan tersebut berupa; (a) pembubaran partai politi, (b) perselisihan hasil pemilihan umum, (d) pemberian putusan Dewan Perwakilan Rakyat atas dugaan pelanggaran yang dilakukan oleh Presiden danatau wakil presiden.

Peranan yang diberikan kepada Mahkamah Konstitusi melalui kewenangannya sebagai sebuah lembaga peradilan oleh UUD RI 1945, mencerminkan semangkin kuatnya penuangan prinsip negara hukum dalam UUD RI 1945 setelah adanya perubahan. Pilar yang sangat fundamental yang diletakkan dalam UUD RI 1945 untuk memperkuat prinsip negara hukum adalah perumusan pada Pasal 1 ayat (2), yang menyatakan bahwa kedaulatan berada ditangan rakyat dan dilaksanakan menurut Undang-Undang Dasar. Dengan adanya perumusan ini, maka Indonesia yang menganut asas demokrasi dalam penyelenggaraan kenegaraan menyandarkan mekanisme demokrasinya kepada hukum, yaitu UUD RI 1945. Hak-hak yang diakui dalam UUD RI 1945 , dan tata cara pelaksanaan demokrasi didalamnya menjadi rambu-rambu bagi pelaksanaan demokrasi. Karena demokrasi tanpa hukum akan mengarah menjadi anarki. Pelanggaran terhadap konstitusi dapat dilakukan dalam beberapa bentuk. Meskipun DPR yang anggotanya dipilih dalam pemilihan umum dan Presiden dipilih secara langsung oleh rakyat, yang berarti keduanya mempunyai dasar legitimasi perwakilan aspiratif, namun, dalam prinsip negara hukum kedua lembaga ini tetap dapat melakukan pelanggaran terhadap konstitusi (Harjono. 2003). Dengan ditetapkannya mekanisme pembuatan undangundang dalam UUD RI 1945, yang melibatkan kedua lembaga ini, DPR dan Presiden, maka produk bersama dari kedua lembaga ini, yaitu undang-undang secara potensial pun dapat menyimpang dari UUD RI 1945. Sebuah undang-undang dapat menjadi objek legislative review, yang dilakukan oleh badan legislative yang membuatnya. Namun, haruslah diingat bahwa legislative review masih tetap didasarkan atas pertimbangan-pertimbangan politik karena memang produk dari lembaga politik. Kehadiran Mahkamah Konstitusi untuk melakukan uji undang-undang adalah untuk menjaga menegakkan konstitusi bilamana terjadi pelanggaran konstitusi oleh undangundang. Dengan mekanisme ini jelas bahwa peranan Mahkamah Konstitusi dalam ketatanegaraan Indonesia adalah untuk menjaga jangan sampai terjadi pelanggaran konstitusi oleh lembaga negara.

$$
\text { Mahkamah Konstitusi yang }
$$

melaksanakan fungsi peradilannya untuk melakukan uji undang-undang harus 
membatasi dirinya jangan samapai menjadi super body dalam pembuatan undang-undang yang terjebak untuk menjadi lembaga yang mempunyai hak "veto" secara terselubung. Dalam hal pembuatan undang-undang harus dipahami secara kesistiman bahwa terdapat tiga kategori substansi dalam konstitusi; (a) pembuat undang-undang diberi kewenangan penuh untuk mengatur dan menetapkan, (b) dalam mengatur dan menetapkan pembuat undang-undang dengan kualifikasi atau pembatasan, (c) pembuat undang-undang tidak diberi kewenangan untuk mengatur dan menetapkan karena telah ditetapkan dan diatur sendiri oleh konstitusi.

UUD RI 1945 telah mendistribusikan kewenangannya kepada beberapalembaga negara. Dalam melaksanakan kewenangan tersebut sangat mungkin akan terjadi dimana satu lembaga negara menggunakan kewenangannya melampaui batas kewenangan yang diberikan kepadanya sehingga melanggar kewenangan lembaga lain. Dengan adanya perubahan UUD RI 1945, hubungan antar lembaga negara diposisikan secara fungsional, dan tidak secara hirarkis, maka diperlukan sebuah lembaga yang secara final dapat memutus perselisihan kewenangan antar lembaga negara. Mahkamah Konstitusi berperan sebagai lembaga peradilan yang memutus sengketa antar kewenangan lembaga negara. Sebelumnya peran ini dilakukan oleh Majelis Permusyawaratan Rakyat dimana sebagai sebuah lembaga pelaksana sepenuhnya kedaulatan rakyat yang omnipotent, yang berwenang untuk melakukan apa saja termasuk didalamnya untuk menmyelesaikan persengketaan yang timbul antar lembaga negara. Dapat diartikan bahwa peran Mahkamah Konstitusi sebagai penjaga konstitusi dalam sistem check and balances antar lembaga negara.

Selanjutnya kita akan melihat bagaimana tata cara pengajuan permohonan ke Mahkamah Konstitusi. Untuk melaksanakan peranannya menjaga konstitusi, Mahkamah Konstitusi dilengkapi dengan mekanisme constitutional control, digerakkan oleh adanya permohonan dari pemohon yang memiliki legal standing untuk membela kepentingannya. Pemilihan kata pemohon dan bukan gugatan yang diajukan kepada Mahkamah Konstitusi bilamana dibandingkan dengan Hukum Acara Perdata, seolah-olah perkara itu merupakan perkara yang bersifat satu pihak (ex parte) dan tidak ada pihak lain yang ditarik sebagai pihak atau termohon dan yang mempunyai hak melawan permohonan tersebut. Hal ini tidak selalu benar, karena dalam jenis perkara tertentu harus ada pihak yang secara tegas ditetapkan dan ditarik sebagai pihak, dan yang mempunyai hak untuk menjawab atau menanggapi permohonan tersebut (Maruarar, Siahaan. 2003).

Peraturan Mahkamah Agung (PERMA) No. 2 tahun 2002 tentang tata cara penyelenggaraan wewenang Mahkamah Konstitusi oleh Mahkamah Agung dalam Pasal 1 ayat (7) dan (8) membedakan permohonan dan gugatan. Terhadpa perkara:

1. Pengujian undang-undang terhadap Undang- Undang Dasar;

2. Sengketa wewenang antar lembaga negara yang kewenangannya diberikan oleh Undang-Undang dasar RI 1945;

3. Memeriksa, mengadili dan memutuskan pendapat Dewan Perwakilan Rakyat bahwa presiden danatau wakil presiden diduga telah melakukan pelanggaran hukum sebagaimana yang dimaksud dalam Pasal 7B ayat (1) UUD RI 1945 dan perubahannya.

Diajukan dalam permohonan yang merupakan permintaan untuk diputus. Di pihak lain jika perkara yang diajukan adalah mengenai:

1. Pembubaran partai politik;

2. Perselisihan hasil pemilihan umum.

Maka harus dengan gugatan yang merupakan tuntutan yang diajukan secara tertulis. Undang-undang No. 24 tahun 2003 menyebutkan bahwa semuanya diajukan dengan permohonan secara tertulis dalam bahasa Indonesia, ditanda tangani oleh pemohon kuasa, diajukan dalam 12 rangkap dan syarat-syarat yang harus dipenuhi disebut dalam Pasal 31 adalah sebagai berikut:

a. Nama dan alamat pemohon; 
b. Uraian mengenai perihal yang menjadi dasar permohonan;

c. Hal-hal yang diminta untuk diputus. Permohonan itu harus pula melampirkan bukti-bukti sebagai pendukung permohonan, yang menunjukkan permohon bersungguh-sungguh. Dengan kata lain, pemohon harus memuat identitas piha-pihak posita dan petitum. Tapi Undang-undang No. 24 tahun 2003 tidak mengharuskan disebut termohon. Karena sifatnya yang lebih banyak melibatkan lembaga-lembaga negara dan khusus tentang pengujian undang-undang terhadap UUD RI 1945, yang berada dalam posisi sebagai termohon tidak terlalu menentukan karena putusan yang diminta adalah bersifat deklaratif terhadap aturan yang berlaku umum juga dilain pihak oleh karena adanya kewajiban Mahkamah Konstitusi memanggil para pihak yang berperkara untuk memberi keterangan yang dibutuhkan danatau meminta keterangan secara tertulis kepada lembaga negara yang terkait dengan termohon, maka yang menentukan termohon itu adalah Mahkamah Konstitusi. Meski tidak secara tegas disebut perlu dimuat siapa yang menjadi termohon, sebagai pihak yang paling berwenang dan berkepentingan menjawab gugatan tersebut, secara praktis dengan penunjukan termohon. Termohon dapat dipanggil untuk memberikan keterangan. Bisa juga dianalogikan keterangan tersebut dengan jawaban dalam Hukum Acara Perdata. Hal ini untuk memenuhi tenggang waktu yang disebut Pasal 4i ayat (3) yang menentukan paling lambat tujuh hari kerja sejak permintaan Hakim Konstitusi diterima, lembaga negara yang bersangkutan wajib menyampaikan penjelasan. Permohonan dapat disatukan dengan panggilan sebagaimana disebutkan dalam Acara Perdata.

Memang secara spesifik dalam perkara pengujian undang-undang terhadap Undang-Undang Dasar tidak disebut siapa yang menjadi termohon, tapi dalam sengketa kewenangan antar lembaga negara, pembubaran partai politik, impeachment, termohon harus ditulis secara tegas. Khusus mengernai sengketa kewenangan antar lembaga negara, Mahkamah Konstitusi dapat mengeluarkan penetapan yang memerintahakan pihak pemohon danatau termohon untuk menghentikan sementara pelaksanaan kewenangan yang dipersengketakan sampai dengan putusan Mahkamah Konstitusi. Tanpa adanya penyebutan termohon secara tegas dalam penetapan yang sifatnya menghentikan kewenangan sementara, maka putusan itu boleh jadi tidak mempunyai arti apa-apa, karena tidak jelas siapa yang wajib melaksanakan perintah tersebut. Hal yang lebih tegas lagi adalah ketika permohonan untuk membatalkan hasil pemilu dan pembubaran partai politik dikabulkan, maka harus jelas siapa yang wajib melaksanakan keputusan hakim Mahkamah Konstitusi tersebut.

Mahkamah konstitusi memeriksa, mengadili dan memutus dalam sidang plenonya dengan sembilan (9) Hakim Konstitusi, akan tetapi dalam keadaan luar biasa dengan tujuh (7) Hakim. Itulah sebabnya surat permohonan diajukan dua belas (12) rangkap, karena disamping dibagikan pada sembilan (9) Hakim, juga harus disampaikan kepda presiden dan DPR dalam waktu tujuh (7) hari sejak permohonan dicatat dalam register perkara konstitusi. Mahkamah Agung, menurut Pasal 53 cukup diberi tahu tentang permohona judicial review. Namun, tidak diatur secara tegas bahwa permohonan disampaikan ke Mahkamah Agung, yang mempunyai arti bahwa tidak perlu diberkanan copy surat permohonan. Salah satu perbedaan dengan gugatan dalam perkara perdata adalah permohonan yang diajukan kepada Mahkamah Konstitusi untuk dapat didaftar harus telah menyertakan alat bukti yang mendukung permohonan tersebut (Pasal 32 ayat (2) dan (3) UU No. 24 tahun 2003). Karena masih ada proses untuk memeriksa perkara dan alat-alat bukti, maka hal ini harus ditafsirkan sebagai bukti awal yang menunjukkan kesungguhan permohonan tersebut dan bukan hanya bertujuan untuk menimbulkan sensasi atau uji coba.

Yang berhak mengajukan permohonan ke Mahkamah Konstitusi adalah setiap orang yang memiliki kepentingan hukum atau kewenangan yang dilanggar dan dirugikan 
dengan kata lain bahwa yang bersangkutan harus mempunya legal standing untuk mengajukan permohonan. Pemohon untuk setiap jenis perkara konstitusi berbeda.

\section{Kesimpulan}

Berdasarkan uraian tersebut diatas, maka dapat menarik kesimpulan sebagai berikut :

1. Salah satu produk informasi ketatanegaraan yang kita bangun setelah perubahan pertama (1999), kedua (2000), ketiga (2001), dan keempat (2002), UUD 1945 adalah dibentuknya MK yang kedudukannya sederajat dengan dan diluar Mahkamah Agung (MA). MK dibentuk dengan maksud mengawal dan menjaga agar konstitusi sebagai Hukum tertinggi (the supreme law of the land ) benar-benar dijalankan atau ditegakan dalam penyelenggaran kehidupan kenegaraan sesuai dengan prinsip-prinsip negara Hukum modern, dimana Hukumlah yang menjadi factor bagi penentu bagi keseluruhan dinamika kehidupan sosial, ekonomi, dan politik suatu bangsa.

2. Menurut Undang-Undang Dasar 1945, kewajiban dan kewenangan Mahkamah Konstitusi adalah :

a. Berwenang mengadili pada tingkat pertama dan terakhir yang putusnya bersifat final untuk:

- Menguji Undang-undang terhadap Undang-Undang Dasar 1945

- Memutus sengketa kewenangan lembaga Negara yang kewenangannya diberikan oleh UUD 1945

- Memutuskan pembubaran partai politik, dan

- Memutuskan perselisihan tentang hasil Pemilihan Umum

- Wajib memberi putusan atas pendapat Dewan Perwakilan Rakyat mengenai dugaan pelanggaran oleh Presiden dan/atau Wakil Presiden menurut UUD 1945

b. Mahkamah Knstitusi wajib memberikan putusan atas pendapat DPR bahwa Presiden dan Wakil
Presiden diduga telah melakukan pelanggaran hukum beruppa pengkhiyanatan terhadap Negara, penyuapan, tindak pidana berat lainnya, atau perbuatan tercela, dan /atau tidak lagi memenuhi syarat sebagai Presiden dan / atau Wakil Presiden sebagaimana dimaksud dalam Undang-Undang Dasar Neagra Indonesia Tahunjh 1945, yaitu :

1. Penghianatan terhadap Negara adalah tindak pidana terhadap keamanan Negara sebagaimana dimaksud dalam Undang-Undang.

2. Korupsi dan penyuapan adalah tindak pidana korupsi atau penyuapan sebagaiana diatur dalam Undang-Undang.

3. Tindak pidana berat lainnya adalah tindak pidana yang diancam dengan pudana penjara 5 (lima ) tahun atau lebih

4. Perbuatan yang tercela adalah perbuatan yang dapat merendahkan martabat Presiden dan /atau Wakil Presiden.

5. Tidak lagi memenuhi syarat sebagai Presiden dan/ Wakil Presiden adalah syarat sebagaimana ditentukan dalam pasal 6 Undang-Undang Dasar Negara Republik Indonesia Tahun 1945

\section{DAFTAR PUSTAKA}

Bambang Waluyo. Penelitian Hukum Dalam Praktek. Sinar Grafika. Jakarta. 1991.

Bambang Sunggono. Metode Penelitian Hukum. Raja Grafindo Persada. Jakarta. 1997.

Bambang Sutiyoso dan Sri Hartuti Puspitasari. Aspek-Aspek

Pengembangan

Kekuasaan

Kehakiman Di Indonesia. UII Press. Jogjakarta. 2005.

Jimly Asshidiqqie. Mahkamah Konstitusi RI. Pengantar. Cetak Biru. Membangun Mahkamah Konstitusi Sebagai Institusi Yang Modern Dan Bertanggung Jawab. Jakarta. 2004. 
Johansyah, Kedudukan Mahkamah Konstitusi Sebagai Lembaga Negara Berdasarkan Undang-Undang Dasar 1945, halaman 94-105

,Model-Model Pengujian

Konstitusional di Berbagai Negara.

Konstitusi Press. Jakarta. 2005.

, Mahkamah Konstitusi Dalam Sistem

Ketatanegaraan Republik Indonesia.

Bahan Ceramah Pada Univ. Mataram, Tanggal 27 September 2005.

Moch. Koesnoe. Dikutip oleh Benny K Harman. Konspigurasi Politik Dan Kekuasaan Kehakiman di Indonesia. ELSAM. Jakarta. 1997.

Zoelva, Hamdan. Impeachment Presiden, Alasan-Alasan Tindak Pidana Pemberhentian Presiden Menurut UUD 1945. Konstitusi Press. Jakarta. 2005.

Ketetapam MPR RI No. IX/MPR/2000 Tentang Badan Pekerja MPR Untuk Perubahan UUD 1945.

Panitia Ad Hoc Badan Pekerja MPR RI Untuk Perubahan UUD 1945. Tahun 2000 . 